Hydrology and Earth System Sciences, 5(3), 311-325 (2001) @ EGS

\title{
Response of sulphur dynamics in European catchments to decreasing sulphate deposition
}

\author{
A. Prechtel ${ }^{1}$, C. Alewell ${ }^{1}$, M. Armbruster ${ }^{2}$, J. Bittersohl 3 , J.M. Cullen ${ }^{4}$, C.D. Evans ${ }^{4}$, R. \\ Helliwell ${ }^{5}$, J. Kopácek ${ }^{6}$, A. Marchetto ${ }^{7}$, E. Matzner ${ }^{1}$, H. Meesenburg ${ }^{8}$, F. Moldan ${ }^{9}$, K. Moritz ${ }^{3}$, \\ J. Veselý ${ }^{10}$ and R.F. Wright ${ }^{11}$
}

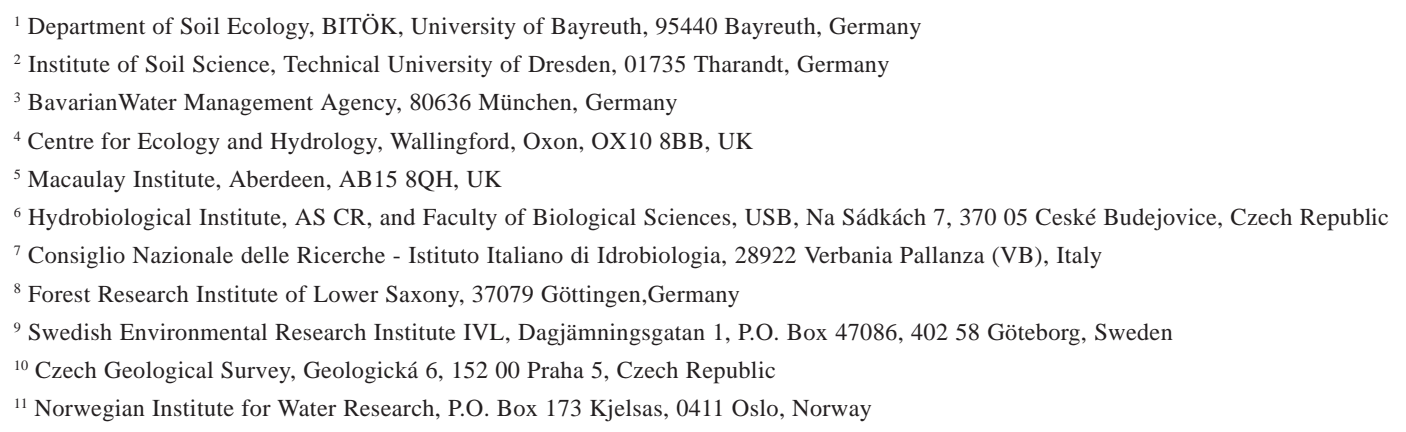

Email for corresponding author: Annette.Prechtel@bitoek.uni-bayreuth.de

\begin{abstract}
Following the decline in sulphur deposition in Europe, sulphate dynamics of catchments and the reversibility of anthropogenic acidification of soils and freshwaters became of major interest. Long-term trends in sulphate concentrations and fluxes in precipitation/throughfall and freshwaters of 20 European catchments were analysed to evaluate catchment response to decreasing sulphate deposition. Sulphate deposition in the catchments studied declined by $38-82 \%$ during the last decade. Sulphate concentrations in all freshwaters decreased significantly, but acidification reversal was clearly delayed in the German streams. In Scandinavian streams and Czech/Slovakian lakes sulphate concentrations responded quickly to decreased input. Sulphate fluxes in run-off showed no clear trend in Germany and Italy but decreased in Scandinavia, the Czech Republic and Slovakia. The decrease, however, was less than the decline in input fluxes. While long-term sulphate output fluxes from catchments were generally correlated to input fluxes, most catchments started a net release of sulphate during the early 1990 s. Release of stored sulphate leads to a delay of acidification reversal and can be caused by four major processes. Desorption and excess mineralisation were regarded as the most important for the catchments investigated, while oxidation and weathering were of lesser importance for the longterm release of sulphate. Input from weathering has to be considered for the Italian catchments. Sulphate fluxes in German catchments, with deeply weathered soils and high soil storage capacity, responded more slowly to decreased deposition than catchments in Scandinavia and the Czech Republic/Slovakia, which have thin soils and relatively small sulphate storage. For predictions of acidification reversal, soil characteristics, sulphur pools and their dynamics have to be evaluated in future research.
\end{abstract}

Keywords: acidification reversal, sulphur, sulphate release, Europe, catchments, deposition, lake, stream

\section{Introduction}

From the beginning of the twentieth century, sulphur (S) emissions and deposition increased steadily (Erisman and Draaijers, 1995; Mylona, 1996) and sulphate $\left(\mathrm{SO}_{4}\right)$ deposition in forested ecosystems of north and central Europe reached more than $100 \mathrm{~kg} \mathrm{ha}^{-1} \mathrm{yr}^{-1}$ in the early $1980 \mathrm{~s}$ (Erkenberg, 1991). Part of the deposited $\mathrm{SO}_{4}$ has accumulated in the soils through adsorption processes
(Johnson and Mitchell, 1998). When the $\mathrm{SO}_{4}$ retention capacity of soils is exceeded, $\mathrm{SO}_{4}$ is leached to deeper soil layers and freshwaters. Because $\mathrm{SO}_{4}$ release is always accompanied by cation leaching, net loss from soils will cause soil acidification (depletion of calcium (Ca), magnesium $(\mathrm{Mg})$, potassium $(\mathrm{K})$ and sodium $(\mathrm{Na})$ pools) as well as acidification of soil solutions and freshwaters (leaching of aluminum $(\mathrm{Al})$, protons $\left(\mathrm{H}^{+}\right)$, iron $(\mathrm{Fe})$ and 
manganese (Mn)) under conditions of low soil pH. Such conditions are common in acid forest soils of temperate regions.

Net release of $\mathrm{SO}_{4}$ from forested soils can be caused by four major processes (i) desorption of inorganic $\mathrm{SO}_{4}$,(ii) oxidation of reduced $\mathrm{S}$ species, (iii) excess mineralisation of organically bound S and (iv) weathering of S-containing minerals. Understanding and prediction of the reversal of soil and water acidification necessitates differentiation between these release processes. While $\mathrm{SO}_{4}$ desorption is an abiotic process regulated by concentration gradients and binding partners for $\mathrm{SO}_{4}$, mineralisation and oxidation are biologically controlled and thus dependent on parameters influencing the physiology of micro-organisms (e.g. temperature, water regime, availability of organic substrates etc.). In contrast, the release of $\mathrm{S}$ by weathering should be relatively stable in time as long as the climate does not show major changes.

Political initiatives such as the S Emissions Control Protocols of 1985 and 1994 of the United Nations Economic Commission for Europe (UNECE) have achieved a $60 \%$ decline in S emissions in Europe (1980-1997) (EMEP, 1999). As $\mathrm{SO}_{4}$ deposition to ecosystems declined, questions concerning the reversibility of anthropogenic acidification of soils and waters and the dynamics of ecosystem recovery were raised. Generally, it can be stated that freshwaters from catchments with a low storage capacity for $\mathrm{SO}_{4}$ react relatively quickly to reduced deposition with an increase in the acid neutralisation capacity (ANC) and $\mathrm{pH}$ as signs of acidification reversal (Stoddard et al., 1999; Tipping et al., 2000; Wright et al., 1994). In contrast, reversal of water acidification can be delayed for decades in regions where previously stored $\mathrm{SO}_{4}$ is released from deeply weathered soils with a high $\mathrm{SO}_{4}$ storage capacity (Alewell et al., 2000; Armbruster, 1998; Kopácek, et al. 2001a; Manderscheid et al. 2000; Veselý et al. 1998a).

As part of the EU project "RECOVER:2010 - Predicting recovery in acidified freshwaters by the year 2010 and beyond" (see Ferrier et al., 2001) evaluated here are: (i) regional differences in long-term trends of $\mathrm{SO}_{4}$ concentrations and fluxes in bulk precipitation/throughfall and freshwaters on a European scale; (ii) the catchment response to decreasing $\mathrm{SO}_{4}$ deposition regarding $\mathrm{SO}_{4}$ concentrations and fluxes as well as budgets; and (iii) the processes responsible for $\mathrm{SO}_{4}$ release in the investigated catchments.

\section{Methods}

The long-term data used in this study were collected within national projects described elsewhere. This study includes
20 European catchments, covering a wide variety of bedrock, soils, and vegetation types as well as deposition and acidification levels (Tables $1 \mathrm{a}$ and $1 \mathrm{~b}$; Fig. 1). For the Czech and the Slovakian catchments, lake water was considered instead of catchment run-off. References for detailed descriptions of sampling methods and site characteristics as well as the time periods of the data used are listed in Table 1c.

Sulphate fluxes in throughfall were taken as total atmospheric $\mathrm{SO}_{4}$ input for the forested catchments in Germany and Sweden, following the reasoning of Mayer and Ulrich (1974), Bredemeier (1988), Johnson and Mitchell (1998) and Alewell (2001a). At the Norwegian and UK sites, bulk precipitation was measured and total deposition (= wet and dry deposition) was calculated from chloride $(\mathrm{Cl})$ mass balances (total $\mathrm{SO}_{4}$ deposition $=\mathrm{SO}_{4}$ fluxes with wet deposition multiplied by the ratio of $\mathrm{Cl}$ flux with run-off to $\mathrm{Cl}$ flux with wet deposition). For the Italian catchments, dry deposition was added as a fixed percentage of wet deposition to calculate total deposition (for details see Rogora et al., 2001). Sulphate input fluxes to Czech catchments were based on fortnightly throughfall and precipitation measurements at Certovo Lake for the 19922000 period and on simulation from long-term $\mathrm{SO}_{4}$ deposition in the Czech Republic before 1991 (Kopácek et $a l ., 2001 b)$. For Lake Vysne Wahlenbergovo, $\mathrm{SO}_{4}$ input was also simulated from long-term deposition trends at Chopok station (monthly data) (Kopácek et al., 2001b).

Input flux calculations were based on samples collected daily (Birkenes, Langtjern, Storgama), weekly (Allt a'Mharcaidh, Risdalsheia, Schluchsee, and Villingen: weekly till 1990, after 1990 samples were combined to monthly bulk samples before analyses), fortnightly (Gårdsjön, Lehstenbach, Markungsgraben, Metzenbach) or monthly (Gårdsjön, Lange Bramke). Sulphate concentrations in bulk precipitation measured weekly at Pallanza (Italy) were taken to be representative for the Italian catchments Cannobino, Pellino, Pellesino, and Pescone where only the amount of precipitation was determined.

Sampling frequencies for $\mathrm{SO}_{4}$ concentrations in streams were weekly at Allt a'Mharcaidh, Birkenes, Langtjern, Storgama, Lange Bramke, Schluchsee and Villingen, fortnightly at Lehstenbach, Markungsgraben and Metzenbach, and monthly at Cannobino, Pellino, Pellesino and Pescone. At Risdalsheia run-off was sampled for each 10-20 mm and at Gårdsjön sampling frequency was proportional to flow. Lake waters in the Czech Republic and Slovakia were sampled once a year in July or August; for output fluxes at Czech and Slovakian sites concentrations were multiplied by annual discharge (see Kopácek et al., 2001b). Weekly, fortnightly or monthly fluxes were 
Table 1a. Site characteristics of catchments studied: location, area, climate and catchment discharge

\begin{tabular}{|c|c|c|c|c|c|c|c|c|}
\hline Catchments & Country & $\begin{array}{c}\text { Latitude } \\
\mathrm{N}\end{array}$ & $\begin{array}{l}\text { Location } \\
\text { Longitude } \\
\text { E }\end{array}$ & $\begin{array}{l}\text { Altitude } \\
\text { m a.s.l. }\end{array}$ & $\begin{array}{c}\text { Area } \\
\text { ha }\end{array}$ & $\begin{array}{l}\text { C } \\
\text { temperature } \\
{ }^{\circ} \mathrm{C} \\
\end{array}$ & $\begin{array}{l}\text { mate } \\
\text { precipitation }{ }^{* *} \\
\text { myr }^{-1}\end{array}$ & $\begin{array}{c}\text { Annual discharge } \\
\mathrm{myr}^{-1}\end{array}$ \\
\hline Cerné (Bohemian Forest) & Czech Republic & $49^{\circ} 11^{\prime}$ & $13^{\circ} 11^{\prime}$ & 1008 & 129 & 4.3 & 1.36 & 1.16 \\
\hline Čertovo (Bohemian Forest) & Czech Republic & $49^{\circ} 10^{\prime}$ & $13^{\circ} 12^{\prime}$ & 1028 & 87.5 & 4.3 & 1.36 & 1.16 \\
\hline Plešné (Bohemian Forest) & Czech Republic & $48^{\circ} 47^{\prime}$ & $13^{\circ} 52^{\prime}$ & 1090 & 66.6 & 4.3 & 1.36 & 1.16 \\
\hline Vysne Wahlenbergovo (High Tatras) & Slovakia & $49^{\circ} 10^{\prime}$ & $20^{\circ} 01^{\prime}$ & 2145 & 32 & -0.7 to -2.4 & 1.58 & \\
\hline Lange Bramke (Harz) & Germany & $51^{\circ} 52^{\prime}$ & $10^{\circ} 26^{\prime}$ & $535-700$ & 76 & 5.9 & 1.24 & 0.68 \\
\hline Lehstenbach (Fichtelgebirge) & Germany & $50^{\circ} 09^{\prime}$ & $11^{\circ} 52^{\prime}$ & $694-871$ & 420 & 6.0 & $1.00-1.10$ & 0.46 \\
\hline Markungsgraben (Bavarian Forest) & Germany & $48^{\circ} 57^{\prime}$ & $13^{\circ} 25^{\prime}$ & $890-1355$ & 110 & $3.0-6.0$ & $0.80-1.60$ & 1.20 \\
\hline Metzenbach (Spessart) & Germany & $49^{\circ} 54^{\prime}$ & $9^{\circ} 26^{\prime}$ & $385-586$ & 240 & $6.0-7.0$ & $0.70 \cdot 1.10$ & 0.17 \\
\hline Schluchsee (Black Forest) & Germany & $47^{\circ} 49^{\prime}$ & $8^{\circ} 06^{\prime}$ & $1150-1290$ & 11 & 4.4 & $1.87^{\star \star \star}$ & $1.40^{\star \star \star}$ \\
\hline Villingen (Black Forest) & Germany & $48^{\circ} 03^{\prime}$ & $8^{\circ} 22^{\prime}$ & 810-945 & 46.3 & 6.3 & $1.33^{\star \star \star}$ & $0.47^{\star \star \star}$ \\
\hline Cannobino & italy & $46^{\circ} 04^{\prime}$ & $8^{\circ} 42^{\prime}$ & $193-2193$ & 110.4 & & $1.60-2.70$ & 1.45 \\
\hline Pellino & |taly & $45^{\circ} 47^{\prime}$ & $8^{\circ} 04^{\prime}$ & $290-942$ & 17.5 & & $2.00-2.10$ & 1.67 \\
\hline Pellesino & Italy & $45^{\circ} 48^{\prime}$ & $8^{\circ} 04^{\prime}$ & $290-1136$ & 3.1 & & $2.00-2.20$ & 1.70 \\
\hline Pescone & Italy & $45^{\circ} 48^{\prime}$ & $8^{\circ} 24^{\prime}$ & 290-1491 & 17.5 & & $1.90-2.10$ & 1.45 \\
\hline Birkenes & Nonway & $58^{\circ} 23^{\prime}$ & $8^{\circ} 15^{\prime}$ & $200-300$ & 41 & 5.4 & 1.53 & 1.17 \\
\hline Storgama & Norway & $59^{\circ} 01^{\prime}$ & $8^{\circ} 32^{\prime}$ & $580-690$ & 60 & 5.1 & 1.21 & 0.95 \\
\hline Langtjern & Norway & $60^{\circ} 22$ & $9^{\circ} 39^{\prime}$ & $510-750$ & 480 & 3.0 & 0.86 & 0.61 \\
\hline Risdalsheia ROLF Reference & Noway & $58^{\circ} 23^{\prime}$ & $8^{\circ} 19^{\prime}$ & 300 & 0.022 & 5.0 & 1.40 & 1.24 \\
\hline Gårdsjön F1 Control & Sweden & $58^{\circ} 03^{\prime}$ & $12^{\circ} 01^{\prime}$ & $113-170$ & 3.7 & 6.3 & $1.10^{\star \star \star}$ & $0.55^{\star \star \star}$ \\
\hline Allt a'Mharcaidh (Scotland) & United Kingdom & $57^{\circ} 07^{\prime}$ & $3^{\circ} 50^{\prime} \mathrm{W}$ & 350-11111 & 998 & 5.6 & 1.07 & 0.83 \\
\hline
\end{tabular}

*annual mean air temperature

**annual mean

***hydrological years

Table $1 b$. Site characteristics of catchments studied: dominant vegetation, geology and soils

\begin{tabular}{|c|c|c|c|}
\hline Catchments & Forest/Vegetation & Bedrock & Soil type (FAO) \\
\hline $\begin{array}{l}\text { Cerné } \\
\text { Čertovo } \\
\text { Plešné }\end{array}$ & $\begin{array}{l}\text { Norway Spruce } \\
\text { Norway Spruce } \\
\text { Nonway Spruce } \\
\end{array}$ & $\begin{array}{c}\text { mica schist } \\
\text { mica schist } \\
\text { granit }\end{array}$ & $\begin{array}{l}\text { Podzols, Cambisols } \\
\text { Podzols, Cambisols } \\
\text { Podzols, Cambisols }\end{array}$ \\
\hline Vysne Wahlenbergovo & Bare rocks, alpine meadow & granit & Leptosols \\
\hline $\begin{array}{l}\text { Lange Bramke } \\
\text { Lehstenbach } \\
\text { Markungsgraben } \\
\text { Metzenbach } \\
\text { Schluchsee } \\
\text { Villingen }\end{array}$ & $\begin{array}{c}\text { Norway Spruce } \\
\text { Norway Spruce } \\
\text { Spruce, mixed woodland } \\
\text { Decidous Forest dominated by Beech } \\
\text { Norway Spruce } \\
\text { Norway Spruce }\end{array}$ & $\begin{array}{c}\text { Lower Devonian Kahleberg sandstone } \\
\text { granite deeply weathered } \\
\text { granite, gneiss } \\
\text { middle new red sandstone } \\
\text { granite } \\
\text { triassic sandstone }\end{array}$ & $\begin{array}{c}\text { dystric Cambisols } \\
\text { dystric Cambisols and Podzols } \\
\text { Cambisols } \\
\text { Cambisols } \\
\text { haplic Podzol } \\
\text { dystric Cambisols and dystric Planosols }\end{array}$ \\
\hline $\begin{array}{l}\text { Cannobino } \\
\text { Pellino } \\
\text { Pellesino } \\
\text { Pescone }\end{array}$ & $\begin{array}{l}\text { Mixed Deciduous } \\
\text { Mixed Deciduous } \\
\text { Mixed Deciduous } \\
\text { Mixed Deciduous }\end{array}$ & $\begin{array}{c}\text { orthogneiss and micaschist }(60 \%) \\
\text { white granite and granodiorite }(50 \%) \text {, } \\
\text { orthogneisses and micaschists }(30 \%) \\
\text { white granite and granodiorite }(80 \%) \\
\text { white granite and granodiorite }(35 \%) \text {, } \\
\text { orthogneisses and micaschists }(30 \%)\end{array}$ & \\
\hline $\begin{array}{l}\text { Birkenes } \\
\text { Storgama } \\
\text { Langtjern } \\
\text { Risdalsheia } \\
\end{array}$ & $\begin{array}{c}\text { Mixed Coniferous } \\
\text { Individual trees, heather, moorgrass } \\
\text { Mixed Coniferous } \\
\text { Mixed Pine and Birch }\end{array}$ & $\begin{array}{l}\text { granite } \\
\text { granite } \\
\text { gneiss } \\
\text { granite }\end{array}$ & $\begin{array}{l}\text { Podzols } \\
\text { Podzols } \\
\text { Podzols } \\
\text { Podzols } \\
\end{array}$ \\
\hline Gårdsjön & Norway Spruce & gneiss & Podzols \\
\hline Allt a'Mharcaidh & $10 \%$ Native pine wood, Montane veg. & granite & dystric (fibric) Histosols, haplic and cryic Podzols \\
\hline
\end{tabular}


A. Prechtel et al.

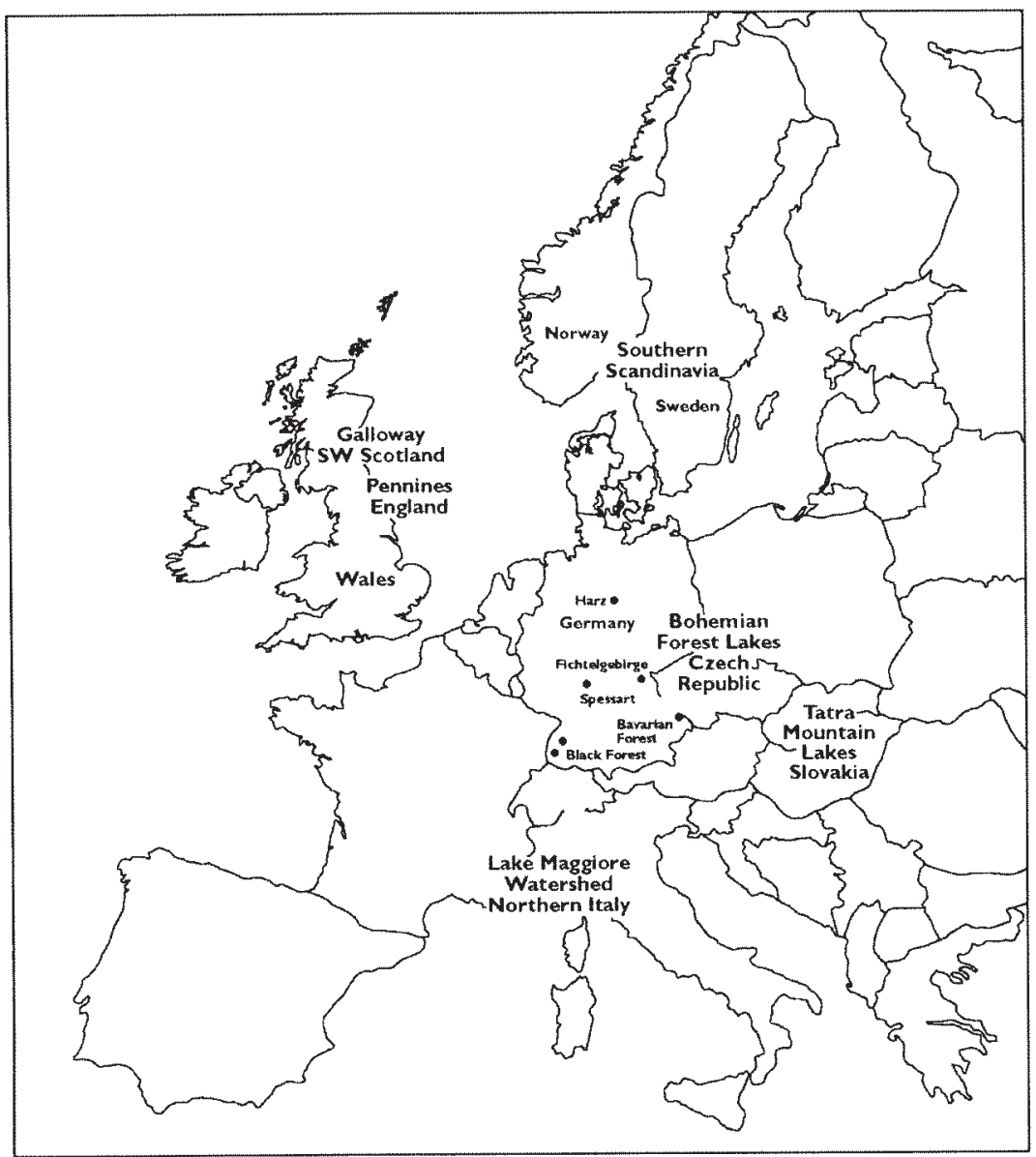

Fig. 1. Map of European catchments included in this study

Table 1c. Data periods and references for detailed descriptions of sampling methods and site characteristics of catchments studied

\begin{tabular}{|c|c|c|}
\hline Catchments & Data periods & References \\
\hline $\begin{array}{c}\text { Cerné } \\
\text { Čertovo } \\
\text { Plešné } \\
\text { Vysne Wahlenbergovo } \\
\text { Lange Bramke } \\
\text { Lehstenbach } \\
\text { Markungsgraben } \\
\text { Metzenbach } \\
\text { Schluchsee } \\
\text { Villingen } \\
\text { Cannobino } \\
\text { Pellino } \\
\text { Pellesino } \\
\text { Pescone } \\
\text { Birkenes } \\
\text { Storgama } \\
\text { Langtjern } \\
\text { Risdalsheia ROLF Reference } \\
\text { Gårdsjön F1 Control } \\
\text { Allt a'Mharcaidh }\end{array}$ & $\begin{array}{l}1990-2000 \\
1990-2000 \\
1990-2000 \\
1980-2000 \\
1983-1995 \\
1988-1998 \\
1989-1998 \\
1988-1998 \\
1988-1996 \\
1988-1995 \\
1985-1999 \\
1985-1997 \\
1986-1997 \\
1985-1997 \\
1974-1999 \\
1975-1999 \\
1974-1999 \\
1986-2000 \\
1989-1999 \\
1986-1994\end{array}$ & $\begin{array}{c}\text { Veselý et al. (1998a), Kopácek et al. (this issue) } \\
\text { Veselý et al. (1998a), Kopácek et al. (this issue) } \\
\text { Veselý et al. (1998a), Kopácek et al. (this issue) } \\
\text { Kopácek et al. (1998), Kopácek et al. (this issue) } \\
\text { Hauhs (1989), Schmidt (1997) } \\
\text { LPW (1994), Manderscheid and Göttlein (1995), Alewell et al. (this issue) } \\
\text { LFW (1994), Alewell et al. (this issue) } \\
\text { LFW (1994), Alewell et al. (this issue) } \\
\text { Armbruster (1998) } \\
\text { Armbruster (1998) } \\
\text { Boggero et al. (1996), Mosello et al. (1993), Rogora et al. (this issue) } \\
\text { Boggero et al. (1996), Mosello and De Giuli (1982), Rogora et al. (this issue) } \\
\text { Boggero et al. (1996), Mosello and De Giuli (1982), Rogora et al. (this issue) } \\
\text { Boggero et al. (1996), Mosello and De Giuli (1982), Rogora et al. (this issue) } \\
\text { Lydersen (1994) } \\
\text { Lydersen (1994) } \\
\text { Lydersen (1994) } \\
\text { Wright et al. (1993) } \\
\text { Moldan (1999) } \\
\text { Ferrier et al. (1990) }\end{array}$ \\
\hline
\end{tabular}


calculated by multiplying concentrations by the equivalent water fluxes; annual output fluxes were then calculated as the yearly sum of weekly, fortnightly or monthly $\mathrm{SO}_{4}$ fluxes. All fluxes analysed are total $\mathrm{SO}_{4}$ fluxes.

For the German catchments Lehstenbach, Markungsgraben and Metzenbach, yearly $\mathrm{SO}_{4}$ fluxes with streams were calculated using the following formula:

$$
\text { Yearly } \mathrm{SO}_{4} \text { flux }=\frac{\left(\Sigma \mathrm{SO}_{4} \text { flux of measurement days }\right) * \text { yearly discharge }}{\Sigma \text { discharge rate of measurement days }}
$$

Yearly output fluxes in Villingen and Schluchsee were calculated according to Brahmer (1990, quoted from Armbruster, 1998), where the sum of water fluxes of a measurement period was multiplied by the arithmetic mean of element concentrations at the start and end point of the measurement period. Yearly element fluxes were calculated by summation of fluxes over all measurement periods. Output fluxes from the Italian streams were calculated according to the approach of Sonzogni et al. (1978) (also see Rogora et al., 2001).

Annual output fluxes were subtracted from input fluxes to calculate the net retention or loss of $\mathrm{SO}_{4}$ in the catchments. All fluxes are shown for calendar years with exception of Gårdsjön, Schluchsee, and Villingen which use hydrological years. For measurement periods see Table 1c.

Trend analysis on $\mathrm{SO}_{4}$ concentrations in precipitation/ throughfall and surface water was done with the SeasonalKendall-Test except for the concentration trends for the Czech lakes and for bulk precipitation at Pallanza for which the Mann-Kendall-Test was used due to low sampling frequencies. Significance limit was set to $p<0.05$. The trend statistic $\mathrm{T}$ gives decrease (negative values) or increase (positive values) in $\mu \mathrm{mol}_{\mathrm{c}} \mathrm{c}^{-1} \mathrm{yr}^{-1}$. A detailed description of statistical methods is given in Evans et al. (2001). To distinguish changes in anthropogenic $\mathrm{SO}_{4}$ from climaterelated variations in sea-salt, deposition trends for Scandinavian catchments were calculated for non-marine sulphate $\left(\mathrm{xSO}_{4}\right.$ ) fraction only (total $\mathrm{SO}_{4}$ minus marine $\mathrm{SO}_{4}$ ). Marine $\mathrm{SO}_{4}$ was calculated based on the $\mathrm{SO}_{4} / \mathrm{Cl}$ ratio of seawater. For central Europe, where marine inputs are minor, non-marine $\mathrm{SO}_{4}$ was considered equal to total $\mathrm{SO}_{4}$.

\section{Results}

\section{TRENDS IN $\mathrm{SO}_{4}$ CONCENTRATIONS}

Starting in the late $1980 \mathrm{~s}, \mathrm{SO}_{4}$ concentrations in bulk precipitation decreased in most catchments (Figs. 2a and 2b). At Lange Bramke this decline started in the early 1980s. Only at Allt a'Mharcaidh in Scotland, UK, was there no significant trend (Mann-Kendall $\mathrm{T}=-0.74, \mathrm{p}>0.05$; data not shown). The absolute decreases were largest in regions receiving the highest deposition (Figs. $2 \mathrm{a}$ and $2 \mathrm{~b}$ ). At the German catchments Lange Bramke, Markungsgraben, Metzenbach and Lehstenbach, the decrease in $\mathrm{SO}_{4}$ concentration in bulk precipitation during the period 1988-

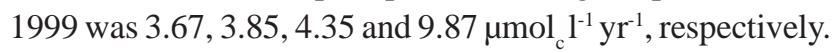
In Villingen and Schluchsee (Black Forest, Germany) trends in $\mathrm{SO}_{4}$ concentrations in bulk precipitation were lower

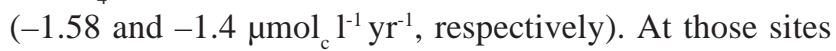
where throughfall data were available, throughfall concentrations (data not shown) generally decreased more than concentrations in bulk precipitation. Sulphate concentrations in throughfall are influenced by interception deposition where the relative decrease is more pronounced. At Lange Bramke, throughfall was measured at the north and south slope as well as at the ridge, and decreased by 9.9, 12.3 and $20.4 \mu_{\mathrm{mol}} \mathrm{l}^{-1} \mathrm{yr}^{-1}$, respectively. For Markungsgraben, Metzenbach and Lehstenbach, decrease in throughfall concentrations was also greater than in bulk precipitation (-13.7, -9.3, $-34.0 \mu \mathrm{mol}_{\mathrm{c}}{ }^{-1} \mathrm{yr}^{-1}$, respectively). Exceptions were Villingen and Schluchsee, where calculated throughfall trends were not significant even though bulk precipitation decreased significantly.

With the decline in $\mathrm{SO}_{4}$ concentrations in precipitation, $\mathrm{SO}_{4}$ concentrations in streams also decreased significantly at all but two sites (Figs. 2a and 2b). The absolute decrease was highest at Gårdsjön (Sweden) and Lehstenbach (Germany). These streams (together with Metzenbach (Germany)) also had the highest mean $\mathrm{SO}_{4}$ concentrations in the 1990s of the sites included here. At Gårdsjön there was a decline in the general level of concentrations, whereas at Lehstenbach base flow concentrations were relatively stable over time and only the maximum concentrations decreased. The Lange Bramke stream showed a small increase for the whole period 1978-99 $\left(1.2 \mu \mathrm{mol}_{\mathrm{c}} \mathrm{l}^{-1} \mathrm{yr}^{-1}\right)$ but a slight decrease since 1987 which, however, was not significant. There was no significant trend in stream concentrations at Allt a'Mharcaidh.

Concentrations in the lakes Cerné, Certovo and Plešné (Czech Republic) decreased significantly (Fig. 2b) and concentrations in lake Vysne Wahlenbergovo (Slovakia) decreased from $80 \mu_{\mathrm{mol}} \mathrm{l}^{-1}$ to around $35 \mu_{\mathrm{mol}} \mathrm{c}^{\mathrm{l}^{-1}}$ (19871999) (trend statistics were not calculated due to major breaks in time series, Fig. 2b).

\section{TRENDS IN $\mathrm{SO}_{4}$ FLUXES AND BUDGETS}

Input fluxes with total deposition at all European catchments started to decrease significantly during the late 1980s parallel to the decrease in concentrations (Figs. $3 a$ and $3 b$ ). The 
A. Prechtel et al.
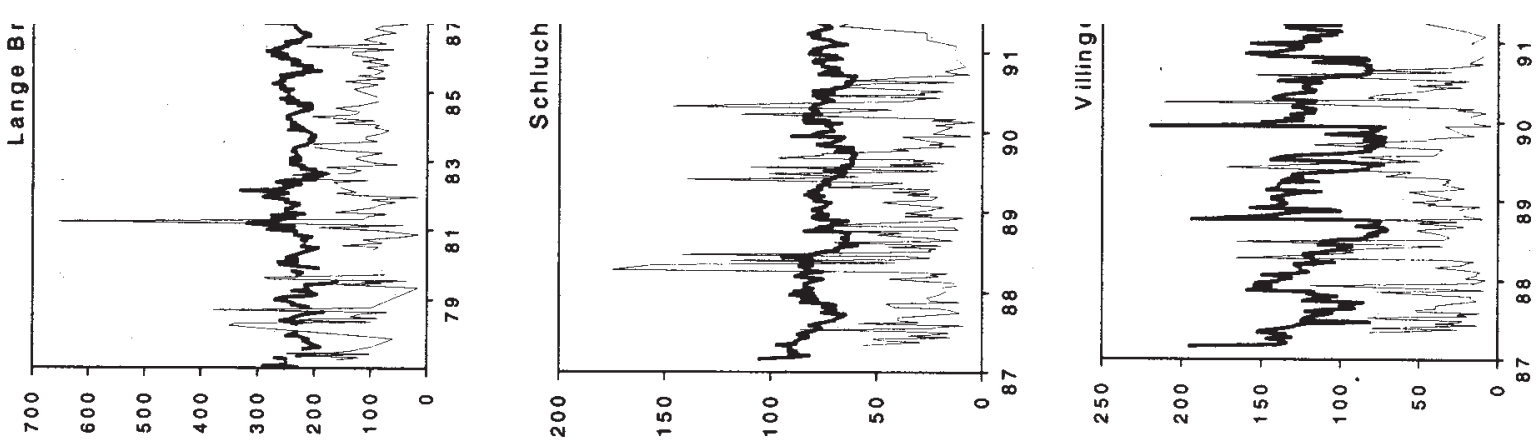

$\left[b^{1} \text { Plownt }\right]_{-z}^{\text {tos }}$

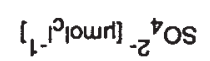
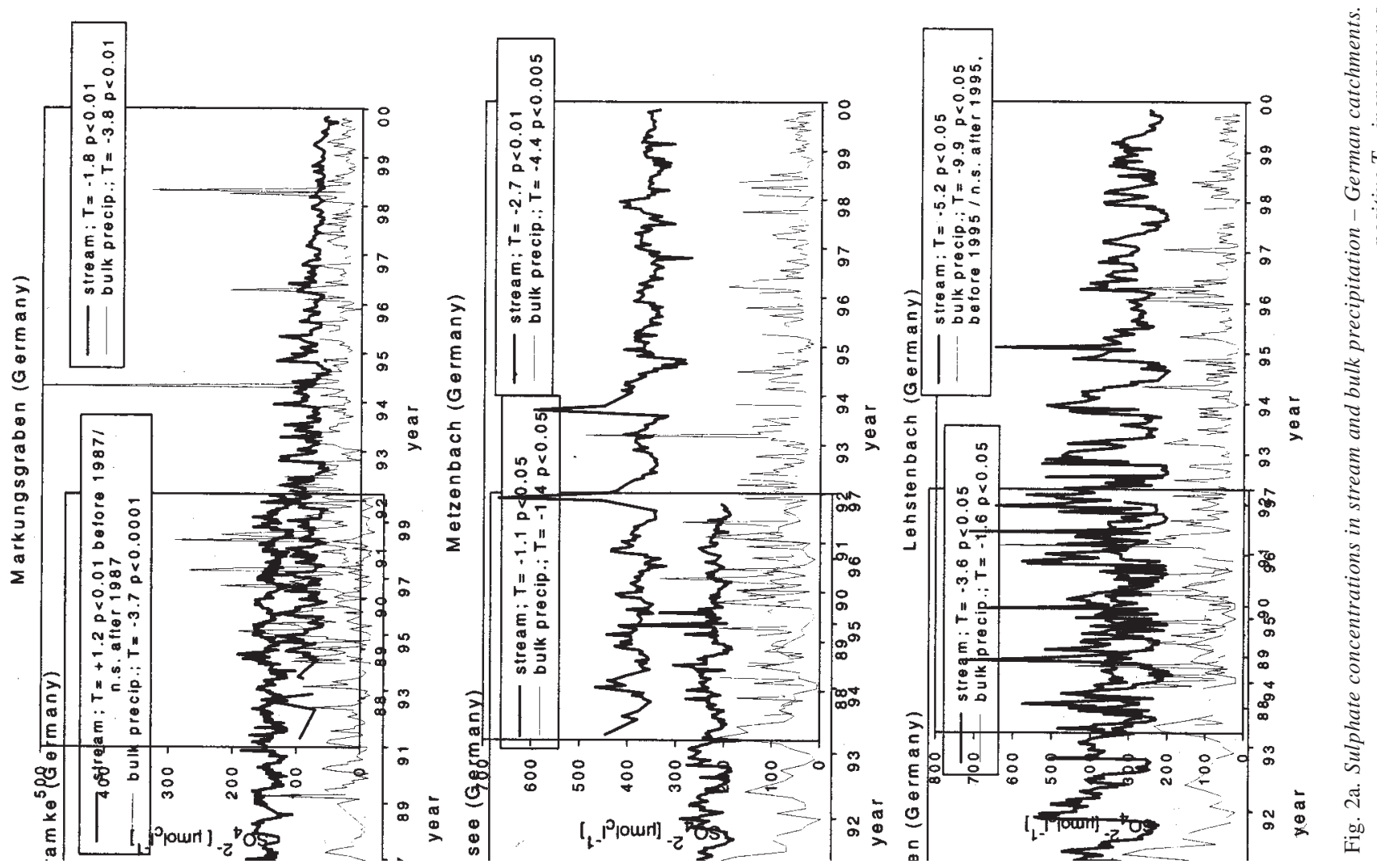

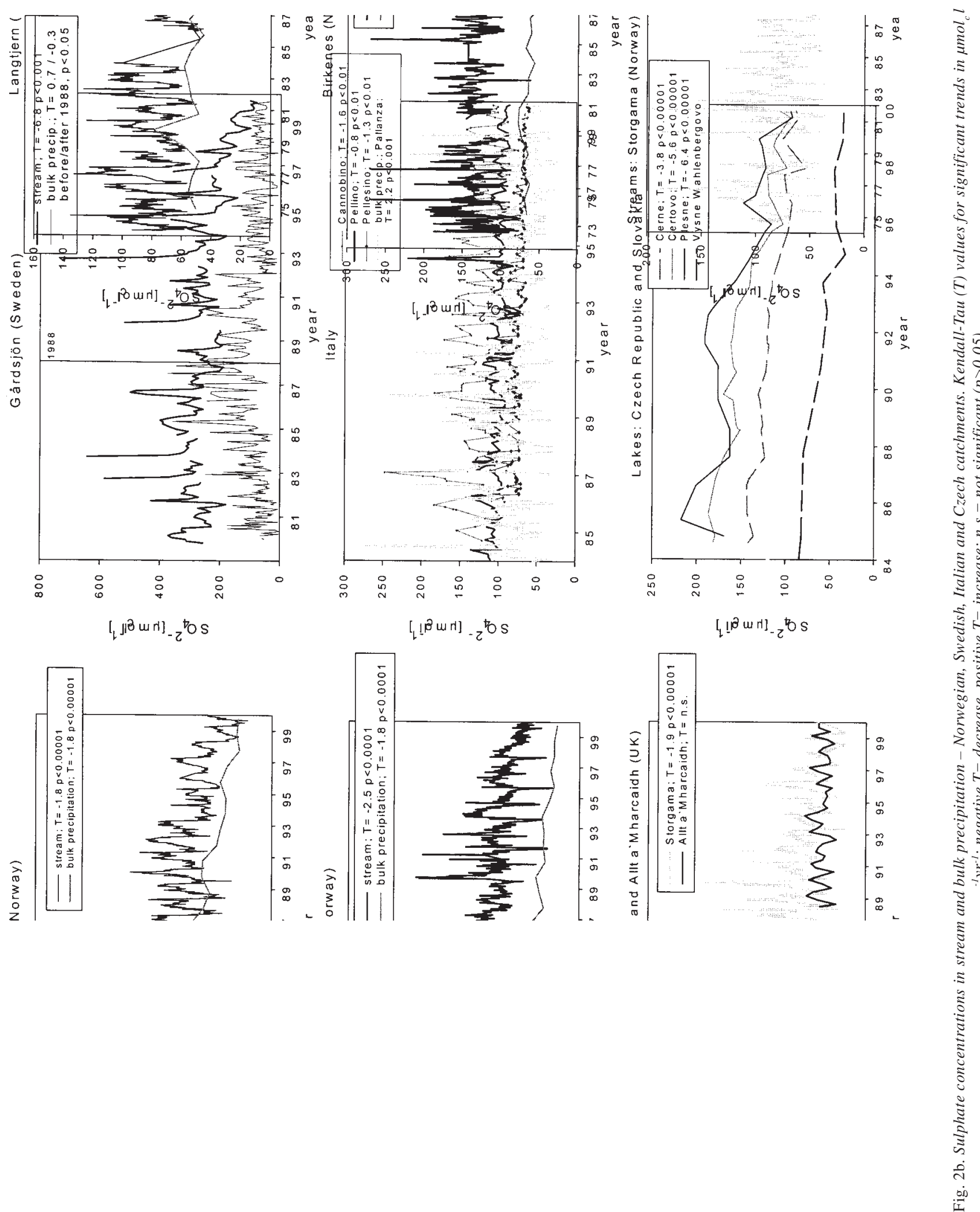


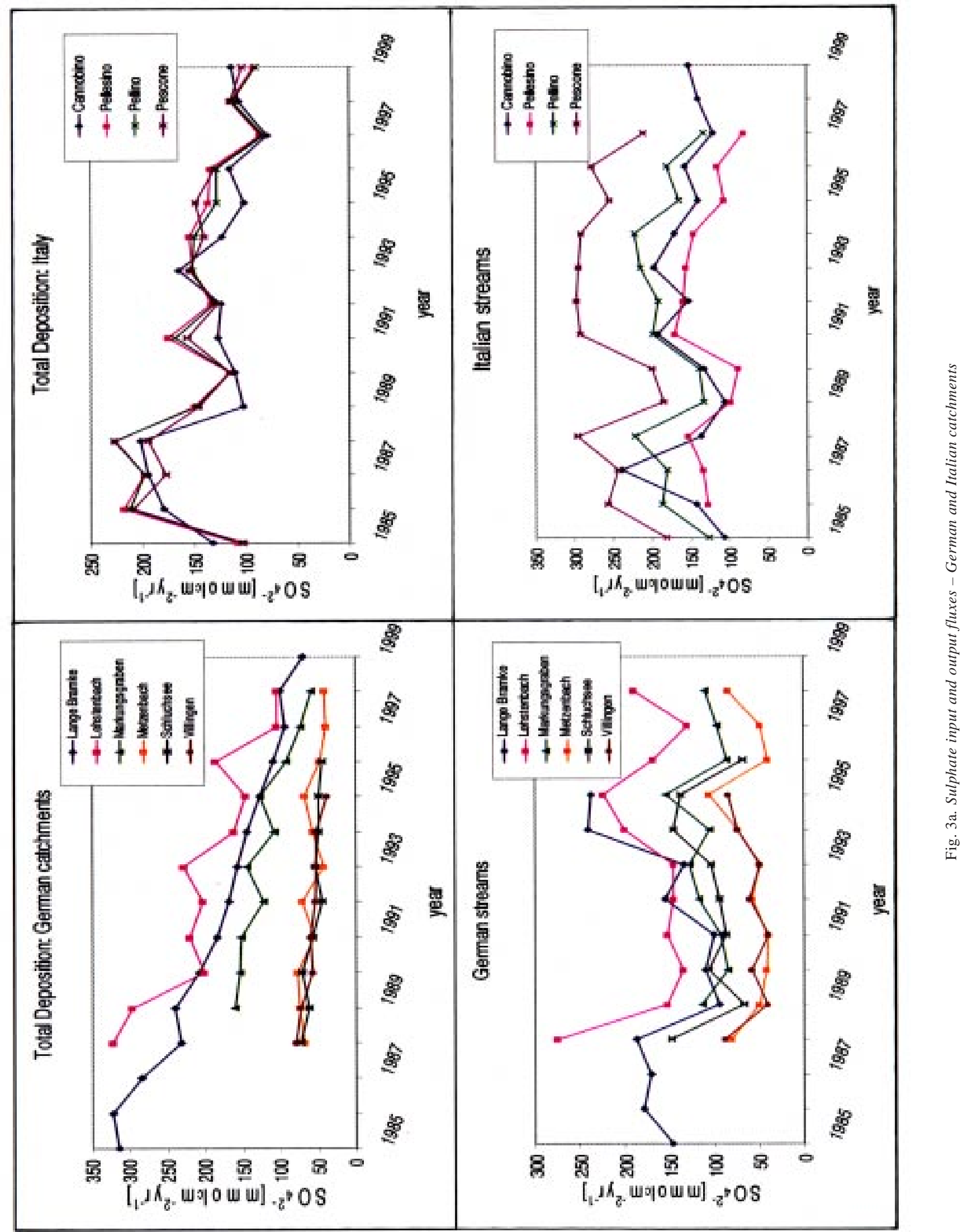




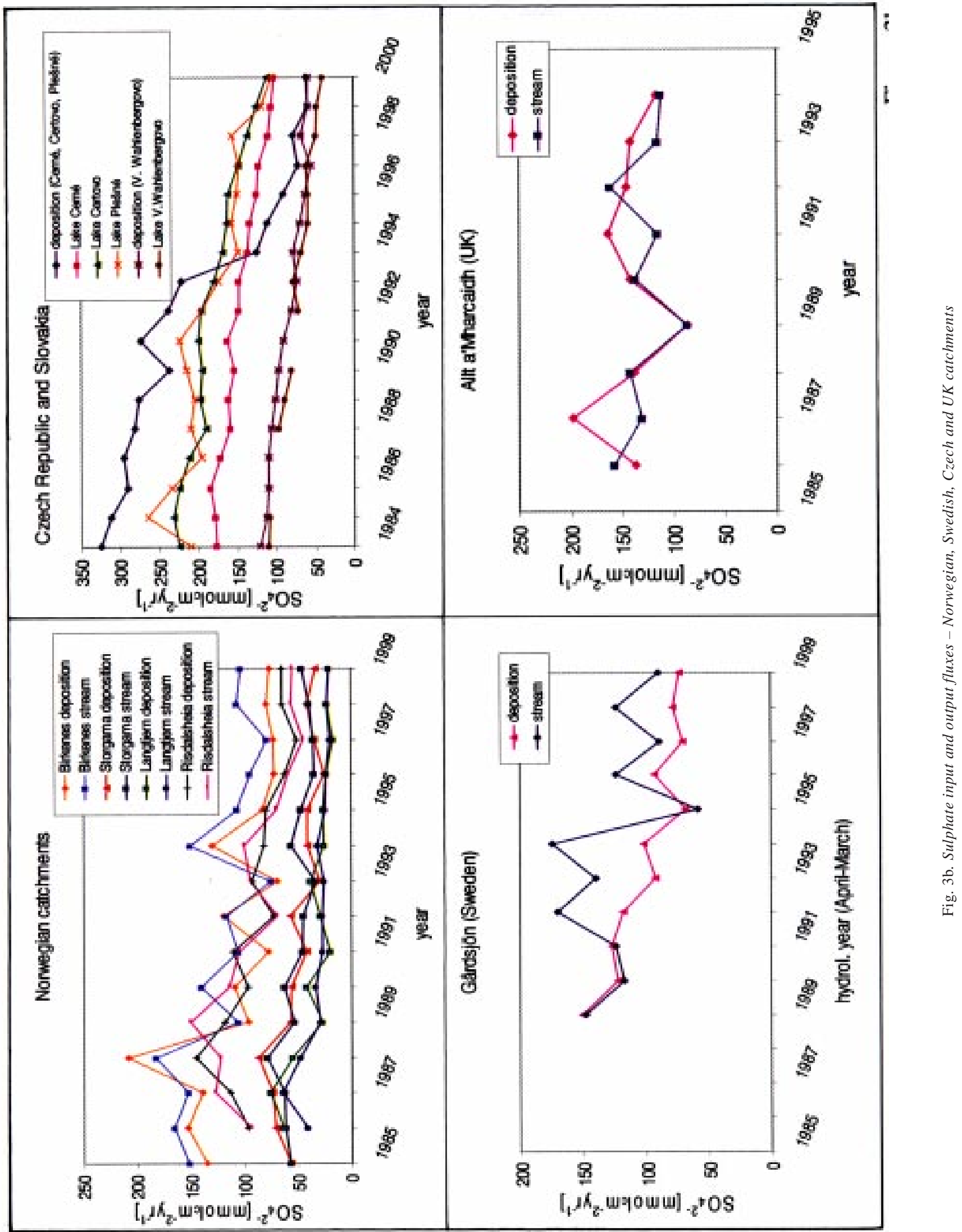


decrease in input fluxes for the period 1988/89 (reference year) to 1998/99 ranged between 38\% (Metzenbach, Schluchsee (1988-1996)) to 70\% (Lange Bramke) at the German catchments, between 43-60\% (Pellino - Cannobino) in Italy, between 53-64\% in Norway and between 78-82\% in the Czech Republic (for the Czech Republic reference year was 1990). The decreases at Slovakian (1980-1999) and Swedish sites (Gårdsjön, 1989-1999) were 48\% and $51 \%$, respectively (Figs. $3 \mathrm{a}$ and $3 \mathrm{~b}$ ).

The German catchments Lange Bramke and Lehstenbach along with the Czech lakes were impacted by the highest $\mathrm{SO}_{4}$ deposition throughout the whole measurement period (for mean input fluxes see Fig. 4). Lehstenbach and Lande Bramke and the Czech lakes also had the highest output fluxes. The catchment wiht he lowest input and outpput fluxes was Langtjern (Norway). There was a positive relationship between yearly mean input load and yearly mean output flux (Fig. 4). An exception is the Italian catchment Pescone which had a higher output relative to input; this is probably due to weathering of S-containing minerals. Another exception is the catchment Schluchsee (Germany) with a medium output $\left(106 \mathrm{mmol}_{\mathrm{c}} \mathrm{m}^{-2} \mathrm{yr}^{-1}\right)$ and only a low input $\left(56 \mathrm{mmol}_{\mathrm{c}} \mathrm{m}^{-2} \mathrm{yr}^{-1}\right)$. Finally, Lange Bramke had a relatively low output compared to input values.

Although the general long-term levels of $\mathrm{SO}_{4}$ input and output fluxes are correlated (Fig. 4), the temporal dynamics of the output fluxes was not parallel to input dynamics. Compared to the major decrease in input fluxes, output fluxes of German and Italian catchments showed no trend (Fig. 3a), partly caused by a high variability in water fluxes (data not shown). The Scandinavian streams, however, showed an overall decrease of output fluxes by 33\% (Birkenes), 40\% (Storgama and Gårdsjön) to 60\% (Risdalsheia) between 1986-1999 (Fig. 3b) parallel to the decrease in deposition. Sulphate output fluxes in the investigated Czech and Slovakian lakes also decreased clearly by between $40-50 \%$ (Fig. $3 b$ ).

The dynamics of $\mathrm{SO}_{4}$ budgets (defined as flux in total deposition minus flux out in run-off) indicated a trend towards negative values (i.e. net loss) in most of the catchments since the late 1980s (Fig. 5). Many sites switched from net retention to net loss, except Pescone (Italy) and Schluchsee (Germany) which lost $\mathrm{SO}_{4}$ since the beginning of measurements in 1985 and 1988 (average loss rates 107.6 $\mathrm{mmol}_{\mathrm{c}} \mathrm{m}^{-2} \mathrm{yr}^{-1}$ and $49.9 \mathrm{mmol}_{\mathrm{c}} \mathrm{m}^{-2} \mathrm{yr}^{-1}$, respectively). The Italian catchments Cannobino and Pellino started releasing $\mathrm{SO}_{4}$ in 1989 and 1990, respectively. Most German catchments started losing $\mathrm{SO}_{4}$ in the early 1990s. The catchments with the highest annual loss rates were Pescone and Lange Bramke with -108 and $-102 \mathrm{mmol}_{\mathrm{c}} \mathrm{m}^{-2} \mathrm{yr}^{-1}$, respectively. Villingen, Gårdsjön, Cannobino, Lehstenbach, Pellino and Schluchsee showed annual loss rates between 34 and $49 \mathrm{mmol}_{\mathrm{c}} \mathrm{m}^{-2} \mathrm{yr}^{-1}$. Lower annual loss rates were observed at Markungsgraben, Birkenes, Metzenbach, Pellesino and Storgama (release $24 \mathrm{mmol}_{\mathrm{c}} \mathrm{m}^{-2} \mathrm{yr}^{-1}$ or less).

At Pellesino (Italy), input fluxes exceeded the output fluxes in run-off in most years, thus showing a net retention of $\mathrm{SO}_{4}\left(14.9 \mathrm{mmol}_{\mathrm{c}} \mathrm{m}^{-2} \mathrm{yr}^{-1}\right)$. Retention of $\mathrm{SO}_{4}$ was also observed at Risdalsheia from 1995 to 2000. The accumulation rate at Risdalsheia, however, was only around

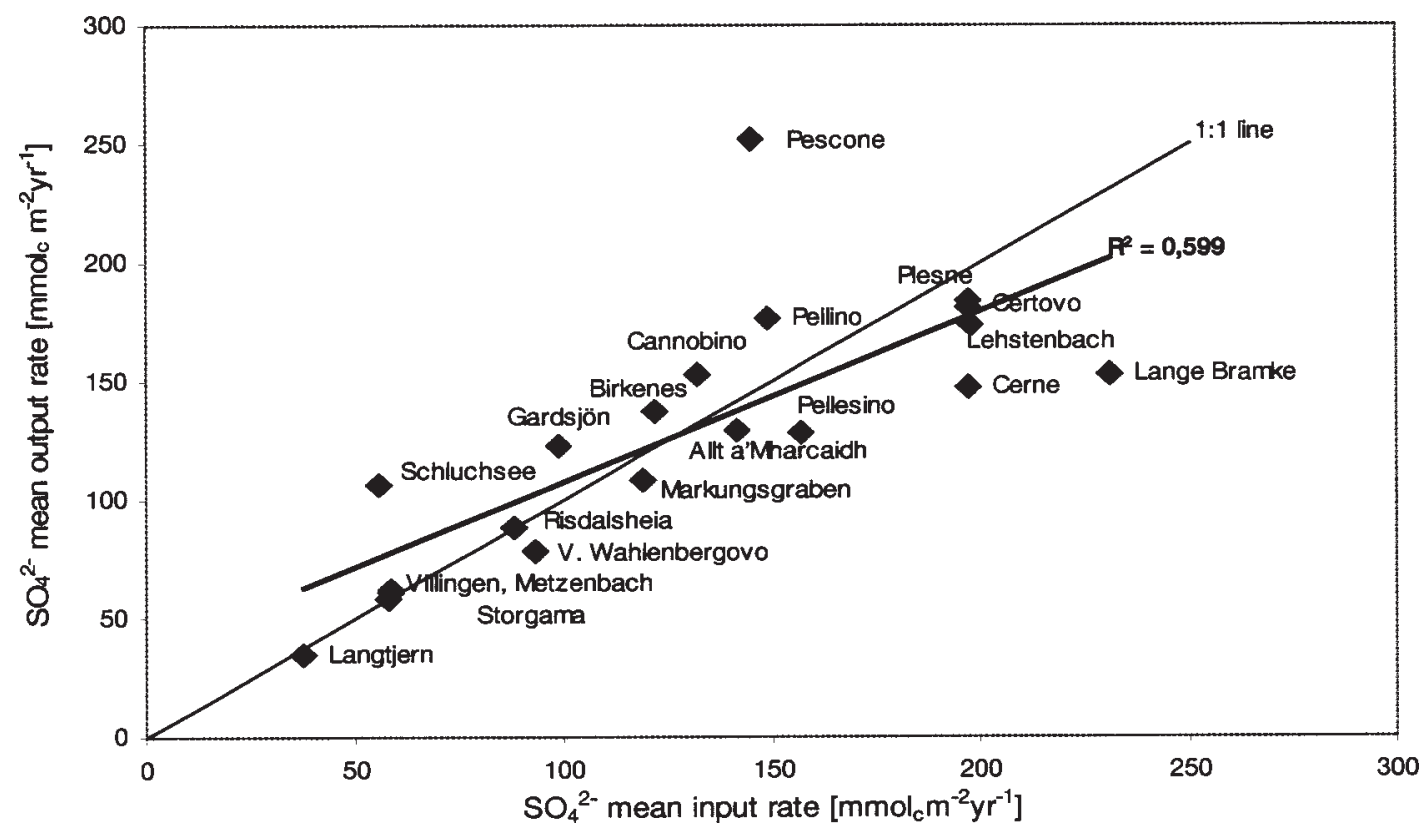

Fig. 4. Mean $\mathrm{SO}_{4}$ input and output fluxes for European catchments (values are calculated for the whole data period; see Table 1c) 


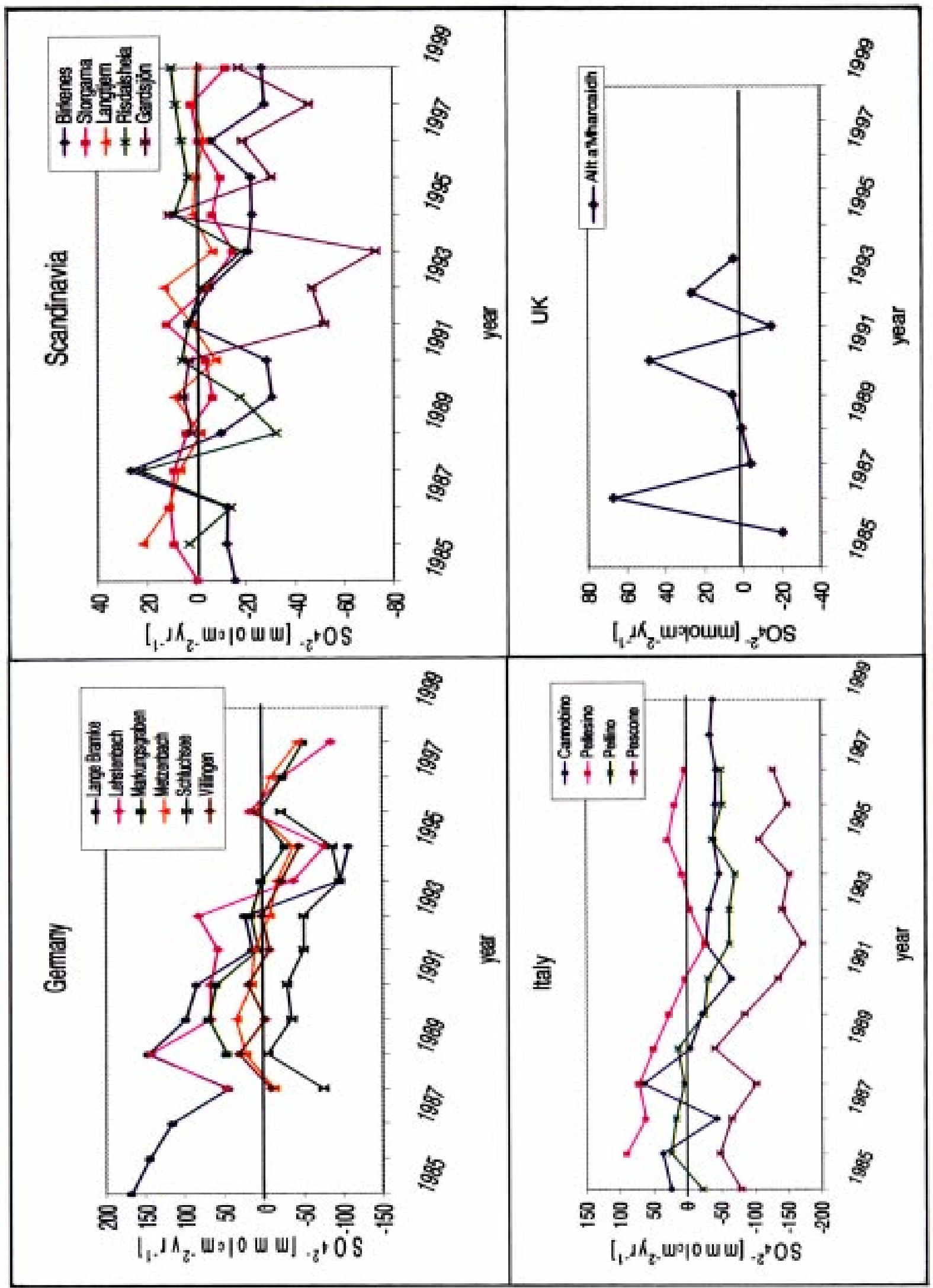


$10 \mathrm{mmol}_{\mathrm{c}} \mathrm{m}^{-2} \mathrm{yr}^{-1}$ and might be within the errors associated with flux measurements. The Scandinavian sites show no major changes in budgets and outputs track inputs closely. At Allt a'Mharcaidh (UK) the budgets showed no clear trend (Fig. 5).

\section{Discussion}

\section{TRENDS IN SO ${ }_{4}$ CONCENTRATIONS AND FLUXES}

The decrease in $\mathrm{SO}_{4}$ deposition during the 1990s in the European catchments investigated ranged between 38 and $82 \%$ (reference year 1988/1989). The catchments with the highest inputs in 1988/1988, such as Lange Bramke, Lehstenbach (Germany) and the Czech catchments also had the greatest decrease (70-82\%) in deposition. At the Italian catchments with high inputs in 1988, the decline was less pronounced (43-60\%). The decreases in deposition at these sites falls into the general pattern for Europe and corresponds to the decline in emissions (Barrett et al., 2000).

All stream sites, with the exception of Lange Bramke and Allt a'Mharcaidh, had significant decreasing trends in $\mathrm{SO}_{4}$ concentrations during the 1990s (Figs. 2a and 2b). Clearly, recovery from high $\mathrm{SO}_{4}$ deposition has occurred but changes in stream concentrations were lower than those in deposition in most catchments. Sulphate was still the dominant strongacid anion in many of the streams (also see Alewell et al., 2001), even though the relative importance of nitrogen (N) deposition is increasing in Europe with decreasing $\mathrm{SO}_{4}$ deposition.

With the exception of the Scandinavian and Slovakian catchments, the response of $\mathrm{SO}_{4}$ fluxes in run-off to reduced deposition has been delayed in most catchments. Despite decreased $\mathrm{SO}_{4}$ concentrations and fluxes in input, several streams had no clear trend in annual output fluxes (e.g. the German, Italian and Scottish streams) or the decrease was less than the reduction in input fluxes, such as at the Czech lakes. This could be due partly to the fact that output fluxes are controlled by hydrology with short-term hydrological variations masking long-term trends in annual $\mathrm{SO}_{4}$ fluxes. However, the results of $\mathrm{SO}_{4}$ fluxes combined with the precipitation and stream concentration trends showed a delayed response in $\mathrm{SO}_{4}$ output in catchments to decreased deposition.

This delay was due to a net release of $\mathrm{SO}_{4}$ from the catchments. At most sites a change in net retention occurred in the late 1980 s or early 1990 s. The consequences of $\mathrm{SO}_{4}$ release into the waters are ongoing cation leaching from soils and thus a delay of acidification reversal of soils and waters. These results confirm studies by Alewell et al. (2000), Veselý et al. (1998b) and Kopácek et al. (2001a) who reported a widespread delay in acidification reversal in ecosystems with a high soil $\mathrm{SO}_{4}$ and proton storage capacity.

The data clearly demonstrate that there is a general relationship between mean $\mathrm{SO}_{4}$ input and mean $\mathrm{SO}_{4}$ output from catchments (Fig. 4). This implies that despite a net release of stored $\mathrm{SO}_{4}$, a reduction in deposition will eventually lead to a reduction in $\mathrm{SO}_{4}$ output.

\section{SULPHUR POOLS AND PROCESSES REGULATING $\mathrm{SO}_{4}$ RELEASE}

The net retention and release of $\mathrm{SO}_{4}$ from the catchments raises the question as to which pools and processes within the ecosystems are involved. Understanding of the sizes of soil S pools and their dynamics will play an important role in the prediction of future $\mathrm{SO}_{4}$ concentrations in streams and, thus, prediction of reversibility of soil and water acidification.

The different development of soils in central and north Europe is reflected in the catchment response of $\mathrm{SO}_{4}$ dynamics. The German catchments Lange Bramke and Lehstenbach have old, deeply-weathered soils and a high soil storage of adsorbed $\mathrm{SO}_{4}$, whereas the Scandinavian, Czech and Slovakian catchments have young, thin soils and thus low $\mathrm{SO}_{4}$ storage capacity. The latter reacted relatively quickly to a decrease in deposition with large decreases in $\mathrm{SO}_{4}$ output flux.

Previous investigations have shown that inorganic soil $\mathrm{SO}_{4}$ pools are sufficiently large to explain a net release by desorption processes for several decades in the catchments Villingen (Armbruster, 1998; Alewell, 2001b), Lange Bramke (Malessa, 1995; Lükewille et al., 1995), Lehstenbach (Manderscheid et al., 2000; Alewell, 1995) and Gårdsjön (Moldan, 1999). Manderscheid et al. (2000) evaluated the $\mathrm{SO}_{4}$ storage in the weathered substrata $(0.5-$ $10 \mathrm{~m}$ depth) of the Lehstenbach catchment and found approximately $90 \mathrm{kmol} \mathrm{ha}{ }^{-1} \mathrm{Na}_{2} \mathrm{HPO}_{4}$-extractable $\mathrm{SO}_{4}$. This $\mathrm{SO}_{4}$ is highly mobile and could be partly released to seepage and run-off for more than 75 years. An interesting result of this analysis is the increasing or constant stream $\mathrm{SO}_{4}$ concentrations at Lange Bramke despite decreasing deposition. Model simulations for Lange Bramke indicated that $\mathrm{SO}_{4}$ concentrations in the stream should increase until 2020 (Lükewille et al. 1995). This prediction was based on measured $\mathrm{SO}_{4}$ pools and an assumed reduction of deposition of 40\% between 1988 and 1993 (Lükewille et al., 1995). The increase in stream water $\mathrm{SO}_{4}$ concentrations is due to net release of adsorbed $\mathrm{SO}_{4}$ from large pools in the deeper soil layers (down to $2.4 \mathrm{~m}$ depth) which function as a longterm memory of the high deposition regime of the past. The 
relatively low $\mathrm{SO}_{4}$ output at Lange Bramke compared to the input flux (Fig. 4) probably reflects $\mathrm{SO}_{4}$ adsorption in deeper soil layers and thus net retention. In contrast to Lange Bramke and Lehstenbach, at Schluchsee (Germany) and Risdalsheia (Norway), the comparison of S fluxes and pools demonstrated that inorganic $\mathrm{S}$ pools are too small to explain $\mathrm{SO}_{4}$ release within the last few decades (Wright et al., 1988; Prietzel, 1998; Armbruster, 1998; Alewell, 2001a). Furthermore, even if inorganic $\mathrm{S}$ pools are large enough to explain a cumulative net loss, this does not exclude underlying $\mathrm{SO}_{4}$ release from other processes.

Excess mineralisation of organic $\mathrm{S}$ (mineralisation > immobilisation and uptake) in soils is another process leading to net release of $\mathrm{SO}_{4}$ to soil solution and run-off. The factors regulating excess mineralisation and the influence of decreased deposition is not yet clear. Stable S isotopes, however, provide a tool for distinguishing between flow paths and processes within ecosystems. Stable isotope investigations have shown a contribution of $\mathrm{S}$ mineralisation to stream water $\mathrm{SO}_{4}$ in several of the catchments; Lehstenbach (Alewell and Gehre, 1999), Gårdsjön (Torssander and Mörth, 1998), Villingen and Schluchsee (Mayer et al., 1995) as well as in two catchments in the Czech Republic (Novak et al., 1995). The stable isotope signature of $\mathrm{S}$, however, can only point to the occurrence of processes and will not yield quantitative estimates of net loss or retention rates. Excess S mineralisation must certainly be considered for the catchments Schluchsee and Risdalsheia, where a comparison of cumulative fluxes over the last decade demonstrated that the organic pool most likely functions as a $\mathrm{SO}_{4}$ source (Alewell, 2001b). In the Schluchsee catchment, however, snowfall is an important part of the total precipitation and $\mathrm{SO}_{4}$ input fluxes in snow are difficult to quantify. This might lead to an underestimation of input fluxes and, thus, account partly for the negative budgets observed at Schluchsee.

Reduction of $\mathrm{S}$ compounds is another mechanism by which $\mathrm{S}$ can be stored in catchments. The oxidation of these compounds can provide a net release of $\mathrm{SO}_{4}$ to run-off. Reduction is a significant sink at Lehstenbach (Alewell and Gehre, 1999) and Schluchsee (Feger et al., 1999). Oxidation of reduced $\mathrm{S}$ takes place when the water table decreases and oxygen-saturated water infiltrates formerly anaerobic zones. The result is a high temporal variability of $\mathrm{SO}_{4}$ retention and release throughout the year. According to Dillon and LaZerte (1992) oxidation of formerly reduced S can function as a long-term source, thus delaying a reduction of $\mathrm{SO}_{4}$ concentrations in stream water at sites with significant pools of reduced S. As long as climate conditions (water regime and soil temperature) are stable, however, $\mathrm{S}$ reduction/oxidation cycles should not influence the long term trends of $\mathrm{SO}_{4}$ concentrations and fluxes in streams.

Sulphate release from weathering of S-containing minerals is a significant source in some areas and might have been underestimated in the past as has been shown for eastern North America (Mitchell et al., 2001). Weathering probably supplies a significant fraction of the $S$ in the Italian catchments investigated. Boggero et al. (1996) suggested that weathering is a S source at Cannobino. Since the bedrock in Pescone and Pellino are similar to Cannobino (Table 1b), a contribution of weathering of S-containing minerals to $\mathrm{SO}_{4}$ net loss from these catchments is also likely. This might explain the relatively high output flux compared to the input flux at Pescone (Fig. 4). A quantitative estimate of the relative importance of $\mathrm{S}$ weathering rates versus the contribution of mineralisation and desorption will be important for a prediction of $\mathrm{SO}_{4}$ release from the Italian catchments. The relatively high uncertainty of the input fluxes to Italian catchments (estimation of dry deposition) makes $\mathrm{S}$ budgets difficult to estimate.

The contribution of weathering of S-containing minerals to the overall $\mathrm{SO}_{4}$ net loss from catchments should not influence trends as long as weathering rates can be assumed to be stable over time. An increase in $\mathrm{S}$ weathering rates would be expected with higher temperatures due to, for example, global warming. A soil survey is planned for the Italian catchments in the year 2001 which will give more insight to $\mathrm{S}$ pools and dominant processes regulating $\mathrm{SO}_{4}$ release at these catchments.

\section{Conclusions}

The 20 European catchments in this study indicated a delayed reduction in stream water $\mathrm{SO}_{4}$ concentration and fluxes in central Europe in response to decreased $\mathrm{SO}_{4}$ deposition with the exception of the Scandinavian catchments where the response in stream water concentrations and fluxes is relatively quick. Although most catchments showed a significant reduction in $\mathrm{SO}_{4}$ concentration in surface waters (and thus reversal of acidification), at several central European catchments this reduction is not yet reflected in the annual $\mathrm{SO}_{4}$ output fluxes. These catchments, with deeply weathered soils and high $\mathrm{SO}_{4}$ storage, have a net release of $\mathrm{S}$ in response to decreased levels of deposition. Sulphate output fluxes at these sites respond later to the deposition change than in catchments with thin soils and relatively low storage capacity, such as those in Scandinavia and the Czech Republic/Slovakia. Sulphate release exceeded input in most catchments since the late 1980s and the early 1990s and this net loss continues. As a consequence, loss of base cations from soils as well as soil and water acidification, can be expected to continue in 
acidified catchments.

Predictions of time scales of reversibility of acidification are dependent on soil S pools and their dynamics. At present it remains difficult to differentiate clearly between processes and pools responsible for net $\mathrm{SO}_{4}$ release into surface waters. Investigation of inorganic and organic $S$ pools and fluxes, weathering rates of $\mathrm{S}$-containing minerals and the contribution of wetland areas ( $\mathrm{S}$ reducing zones) to stream run-off are required.

\section{Acknowledgements}

This project was financially supported by the Commission of European Communities RECOVER:2010 project (project no. EVK1-CT-1999-00018) and the German Ministry of Education and Research, grant no. PT BEO 51-0339476. Sampling and analyses of water and soil at Czech and Slovakian sites were partly supported by GA CR project No 206/00/0063 and the Commission of European Communities project EMERGE (EVK1-CT-1999-00032), respectively. Data for the Norwegian sites come from the national monitoring program operated by the State Pollution Control Authority.

\section{References}

Alewell, C., 1995. Sulfat-Dynamik in sauren Waldböden Sorptionsverhalten und Prognose bei nachlassenden Depositionen. Bayreuther Forum Ökologie, Band 19.

Alewell, C., 2001a. Twenty years reversibility of soil and water acidification in Europe: Mechanisms, Predictions and Consequences. Habilitation Thesis, University of Bayreuth.

Alewell, C. and Gehre, M., 1999. Patterns of stable S isotopes in a forested catchment as indicators for biological $\mathrm{S}$ turnover. Biogeochemistry, 47, 319-333.

Alewell, C., Manderscheid, B., Meesenburg, H. and Bittersohl, J., 2000. Is acidification still an ecological threat? Nature, 407, $856-857$.

Alewell, C., 2001b. Predicting reversibility of acidification: the European sulfur story. Water Air Soil Pollut., (in press).

Alewell, C., Armbruster, M., Bittersohl, J., Evans, C., Meesenburg, H., MJoritz, K. and Prechtel, A., 2001. Are there signs of recovery after two decades of reduced acid input in the low mountain ranges of Germany? Hydrol. Earth Syst. Sci., 5, 367-378.

Armbruster, M., 1998. Zeitliche Dynamik der Wasser- und Elementflüsse in Waldökosystemen. Freiburger Bodenkundl. Abh., 38, 1-301.

Barrett, K., Schaug, J., Bartonova, A., Semb, A., Hjellbrekke, A.G. and Hanssen, J.E., 2000. A contribution from CCC to the reevaluation of the observed trends in sulphur and nitrogen in Europe 1978-1998: Input for further evaluation by the national laboratories and for use in the TFMM assessment work. EMEP/ CCC-Rep. 7/2000, 1-193.

Boggero, A., Belfanti, S., Brizzio, M.C., Calderoni, A. and Mosello, R., 1996. Trends in the chemistry of surface water in north-western Italy. IV. Nitrogen in sub-alpine rivers Pellino, Pellesino, Pescone and Cannobino (Lago Maggiore watershed).
Mem. Ist. Ital. Idrobiol., 54, 143-159.

Brahmer, G., 1990. Wasser- und Stoffbilanzen bewaldeter Einzugsgebiete im Schwarzwald unter besonderer Berücksichtigung naturräumlicher Ausstattungen und atmogener Einträge. Freiburger Bodenkundl. Abh., 25, 1-295.

Bredemeier, M., 1988. Forest canopy transformation of atmospheric deposition. Water Air Soil Pollut., 40, 121-138.

Dillon, P.J. and LaZerte, B.D., 1992. Response of Plastic Lake catchment, Ontario, to reduced sulphur deposition. Environ. Pollut., 77, 211-217.

EMEP, 1999. Transboundary acid deposition in Europe. EMEP emission data. Status report 1999 of the European Monitoring and Evaluation Programme. EMEP/MSC-W Report 1/1999. http://www.emep.int/ladm.html.

Erisman, J.W. and Draaijers, G.P.J., 1995. Atmospheric deposition in relation to acidification and eutrophication. Studies in Environmental Science, 63. Elsevier, Amsterdam, 1-405.

Erkenberg, A., 1991. Schwefelausstattung europäischer Waldböden unter besonderer Berücksichtigung der Adsorptionskapazität von Sulfat. Dissertation, University of München.

Evans, C.D., Cullen, J.M., Alewell, C., Marchetto, A., Moldan, F., Kopácek, J., Prechtel, A., Rogora, M., Veselý, J. and Wright, R.F., 2001. Recovery from acidification in European surface waters. Hydrol. Earth Syst. Sci., 5, 283-297.

Feger, K.-H., Köhler, H. and Armbruster, M., 1999. Beeinflussung der Wasserqualität in einem bewaldeten Einzugsgebiet durch biogeochemische Stoffumsetzungen in bachnahen Böden. Forstw. Cbl., 118, 345-354.

Ferrier, R.C., Walker, T.A.B., Harriman, R., Miller, J.D. and Anderson, H.A., 1990. Hydrological and hydrochemical fluxes through vegetation and soil in the Allt a'Mharcaidh, western Cairngorms, Scotland - their effect on streamwater quality. $J$. Hydrol., 116, 251-266.

Ferrier, R.C., Jenkins, A.,Wright, R.F., Schopp, W. and Barth, H. 2001. Assessment of recovery of surface waters from acidification, 1970-2000: Introduction to the Special Issue. Hydrol. Earth Syst. Sci., 5, 274-282.

Hauhs, M., 1989. Lange Bramke: an ecosystem study of a forested catchment In: Acidic precipitation Vol.1 Case studies, D.C. Adriano and M. Havas. (Eds.), 275-305. Springer, New York.

Johnson, D.W. and Mitchell, M.J., 1998. Responses of forest ecosystems to changing sulfur inputs. In: Sulfur in the environment, D.G. Maynard (Ed.), 219-262. Marcel Dekker, New York.

Kopácek, J., Hejzlar, J., Stuchlik, E., Fott, J. and Vesely, J., 1998. Reversibility of acidification of mountain lakes after reduction in nitrogen and sulphur emissions in central Europe. Limnol. Oceanogr., 43, 357-361.

Kopácek, J., Stuchlik, E., Vesely, J., Schaumburg, J., Anderson, I.C., Fott, J., Hejzlar, J. and Vrba, J., 2001a. Hysteresis in reversal of central European mountain lakes from atmospheric acidification. Water Air Soil Pollut., (in press).

Kopácek, J., Vesely, J. and Stuchlik, E., 2001b. Sulphur and nitrogen fluxes and budgets in the Bohemian Forest and Tatra Mountains during industrial revolution (1850-2000). Hydrol. Earth Syst. Sci., 5, 391-405.

LfW, 1994. Bayerisches Landesamt für Wasserwirtschaft. Auswirkungen des sauren Regens und des Waldsterbens auf das Grundwasser. Dokumentation der Methoden und Meßdaten des Entwicklungsvorhabens 1988-1992. Materialien, 40, 1-387.

Lükewille, A., Malessa, V. and Alewell, C., 1995. Measured and modelled retention of inorganic sulfur in soils and subsoils (Harz Mountains, Germany). Water Air Soil Pollut., 85, 683-688.

Lydersen, E., 1994. Long-term monitored catchments in Norway - A hydrologic and chemical evaluation. Acid Rain Research 
Report 34-A/1994. Norwegian Institute for Water Research, Oslo, Norway, 306 pp.

Malessa, V., 1995. Soil acidification gradients: mode of development, status quo and classification. Water Air Soil Pollut., 84, 303-321.

Manderscheid, B. and Göttlein, A., 1995. Wassereinzugsgebiet Lehstenbach - das BITÖK-Untersuchungsgebiet am Waldstein (Fichtelgebirge, NO-Bayern). Bayreuther Forum Ökologie, 18, $1-84$.

Manderscheid, B., Schweisser, T., Lischeid, G., Alewell, C. and Matzner, E., 2000. Sulfate pools in the weathered substrata of a forested catchment. Soil Sci. Soc. Am. J., 64, 1078-1082.

Mayer, R. and Ulrich, B., 1974. Conclusions on the filtering action of forests from ecosystem analysis. Oecol. Plant., 9, 157-168.

Mayer, B., Feger, K.H., Giesemann, A. and Jäger, H.-J., 1995. Interpretation of sulfur cycling in two catchments in the Black Forest (Germany) using stable sulfur and oxygen isotope data. Biogeochemistry, 30, 31-58.

Mitchell, M.J., Mayer, B., Bailey, S.W., Hornbeck, J.W., Alewell, C., Driscoll, C.T. and Likens, G.E., 2001. Use of stable isotope ratios for evaluating sulfur sources and losses at the Hubbard Brook experimental forest. Water Air Soil Pollut., (in press).

Moldan, F., 1999. Reversal of soil and water acidification in SW Sweden, simulating the recovery process. of chemical loads as applied to Lake Maggiore. Mem. Ist. Ital. Idrobiol., 40, 55-77.

Mosello, R., Brizzio, C., Calderoni, A., Marchetto, A. and Tartari, G.A., 1993. Trends in the chemistry of surface water in northwestern Italy. II. Watershed budget and trends in River Cannobino. Mem. Ist. Ital. Idrobiol., 51, 167-184.

Mylona, S., 1996. Sulphur dioxide emissions in Europe 18801991 and their effect on sulphur concentrations and depositions. Tellus, 48B, 662-689.

Novak, M., Bottrell, S. A., Groscheova, H., Buzek, F. and Cerny, J., 1995. Sulphur isotope characteristics of two north bohemian forest catchments. Water Air Soil Pollut., 85, 1641-1646.

Prietzel, J., 1998. Untersuchungen zur Boden-SchwefelAusstattung zweier Schwarzwaldstandorte - räumliche Variabilität, zeitliche Dynamik und Auswirkungen experimenteller Sulfatgaben. Habilitation Thesis, University of Munich, 1-399.

Rogora, M., Marchetto, A. and Mosello, R., 2001. Trends in the chemistry of atmospheric deposition and surface waters in Lake Maggiore catchment. Hydrol. Earth Syst. Sci., 5, 379-390.

Schmidt, S., 1997. Zusammenhang von Wasser- und Stoffhaushalt in der Langen Bramke - Vergleich unterschiedlicher zeitlicher und räumlicher Maßstäbe. Ber. des Forschungszentrums Waldökosysteme, Reihe A, 146, 1-188.

Sonzogni, W.C., Monteith, T.J., Bach, W.N. and Haughes, V.G., 1978. United States great lakes tributary loadings. International Reference Group on Grate Lakes Pollution from Land Use Activities. International Joint Commission, 1-187.

Stoddard, J.L., Jeffries, D.S., Lükewille, A., Clair, T.A., Dillon, P.J., Driscoll, C.T., Forsius, M., Johannessen, M., Kahl, J.S., Kellogg, J.H., Kemp, A., Mannio, J., Monteith, D., Murdoch, P.S., Patrick, S., Rebsdorf, A., Skjelkvåle, B.L., Stainton, M.P., Traaen, T.S., van Dam, H., Webster, K.E., Wieting, J. and Wilander, A., 1999. Regional trends in aquatic recovery from acidification in North America and Europe 1980-95. Nature, 401, 575-578.

Tipping, E., Bettney, R., Hurley, M.A., Isgren, F., James, J.B., Lawlor, A.J., Lofts, S., Rigg, E., Simon, B.M., Smith, E.J. and Woof, C., 2000. Reversal of acidification in tributaries of the river Duddon (English Lake District) between 1970 and 1998. Environ. Pollut., 109, 183-191.

Torssander, P. and Mörth, C.-M., 1998. Sulfur dynamics in the Roof experiment at Lake Gårdsjön deduced from sulfur and oxygen isotope ratios in sulfate. In: Experimental reversal of acid rain effects: the Gårdsjön roof project, $\mathrm{H}$. Hultberg, and R. Skeffington (Eds.), 185-206. Wiley, Chichester, UK.

Veselý, J., Hruska, J., Norton, S.A. and Johnson, C.E., 1998a. Trends in the chemistry of acidified Bohemian lakes from 1984 to 1995: I. Major solutes. Water Air Soil Pollut., 108, 107-127.

Veselý, J., Hruska, J. and Norton, S.A., 1998b. Trends in the chemistry of acidified Bohemian lakes from 1984 to 1995: II. Trace elements and aluminum. Water Air Soil Pollut., 108, 425443.

Wright, R.F., Lotse, E. and Semb, A., 1988. Reversibility of acidification shown by whole-catchment experiments. Nature, 334, 670-675.

Wright, R.F., Lotse, E. and Semb, A., 1993. RAIN project: results after 8 years of experimentally reduced acid deposition to a whole catchment. Can. J. Fisheries Aquat. Sci., 50, 258-268.

Wright, R.F., Cosby, B.J., Ferrier, R.C., Jenkins, A., Bulger, A.J. and Harriman, R., 1994. Changes in acidification of lochs in Galloway, southwestern Scotland, 1979-1988: The MAGIC model used to evaluate the role of afforestation, calculate critical loads, and predict fish status. J. Hydrol., 161, 257-285. 
A. Prechtel et al. 